Chapter 9

\title{
Determination of Anaerobic and Anoxic Biodegradation Capacity of Sulfamethoxasole and the Effects on Mixed Microbial Culture
}

\author{
Zeynep Cetecioglu, Bahar Ince, Samet Azman, \\ Nazli Gokcek, Nese Coskun and Orhan Ince
}

Additional information is available at the end of the chapter

http://dx.doi.org/10.5772/56049

\section{Introduction}

During last decades, concentration of human and veterinarian antibiotics in the environment, natural and engineered systems have been increased because of high amount production and consumption. This situation has aroused great concern due to the possibility of harmful effects on human, animals and plants [1,2]. Occurrence and fate of these compounds are one of the main issues because of their unknown potential risks and their effects on the environment. Approximately 500 tonnes of them are produced and consumed every year in the worldwide. Antibiotics are resistant to conventional biological treatment process and the wastewaters including these compounds are directly discharged to the receiving water bodies without efficient treatment. Hospitals and pharmaceutical industries are the main sources of high antibiotic concentration release to the environment [3]. Also sewage systems can transport these molecules and/or their metabolites since metabolization of them by humans and animals cannot be achieved completely [4]. During the transportation of antibiotics throughout treatment plants, elimination of these compounds can occur via biodegradation, photolysis and sorption to sludge but ultimate degradation of these compounds cannot be achieved in conventional treatment plants $[4,5,6]$. As a result of the introduction of metabolized and/or active antibiotics to the receiving water bodies caused an increase in the ratio of multiantibacterial resistant pathogens [7].

Sulfamethoxasole (SMX) is a sulfonamide bacteriostatic antibiotic that is used to treat urinary tract infections. SMX inhibits the multiplication of bacteria, since they are competitive inhibitors of $p$-amino benzoic acid in the folic acid metabolism cycle [8]. Sulfonamide antibiotics, 
including SMX, have been found in the activated sludge processes and digested sludges in varying concentration from ng/L to $\mu \mathrm{g} / \mathrm{L}$ levels $[5,8]$. Behaviour of sulfonamide antibiotics has been reported as recalcitrant molecules thus sorption and desorption are the main pathways on antibiotic elimination from aquatic phases $[9,10]$. Biodegradability of SMX has not been widely studied for anaerobic systems. There are few studies about anaerobic biodegradability characteristics of SMX in the literature [11, 12].

In this chapter, the aim is to reveal the anoxic and anaerobic biodegradability characteristics of SMX and the effects of this compound on microbial community. In this scope, biodegradation capacity and the effects on the microorganisms were investigated by destructive batch tests based on a modified version of Anaerobic Biodegradability of Organic CompoundsOECD 311 protocol [13] under three different electron acceptor conditions; nitrate reducing, sulfate reducing, and methanogenic conditions. Quantification of defined microbial groups was also carried out to determine the effects of SMX on abundance of microbial community.

\subsection{Antibiotics}

Antibiotics are among the most important groups of pharmaceuticals and chemotherapeutic agents that inhibit or terminate the growth of microorganisms, such as bacteria, fungi, or protozoa without affecting host [11, 12]. The term antibiotic used for drugs that block any of these microorganisms. Other terms as chemotherapeutics or antimicrobials are not synonymous because of their scopes; the term of antimicrobial is used for the medicine which is also effective against viruses and the expression "chemotherapeutical" referring to compounds used for the treatment of disease which kill cells, specifically microorganisms or cancer cells. The term "chemotherapeutical" may also refer to antibiotics (antibacterial chemotherapy).

The expression of antibiotic is originally used to describe any agent with biological activity against living organisms; however, "antibiotic" now refers to substances with antibacterial, anti-fungal, or anti-parasitical activity. During the years, this definition has been changed and now it includes also synthetic and semi-synthetic products. There are approximately 250 different compounds registered for use in medicine and veterinary application [16].

In this chapter, the term "antibiotic" refers only to drugs that kill or inhibit bacteria. Antibiotics that are sufficiently nontoxic to the host are used as chemotherapeutic agents in the treatment of infectious diseases of humans, animals and plants. They are extensively used for prevention and treatment of diseases caused by microorganisms in human and veterinary medicine as well as in aquaculture nowadays. Also, they are being still used as growth factor in livestock farming. Some compounds may be used for different purposes such as in growing fruit and in bee keeping other than human or veterinary medicine. The application purposes may vary from country to country.

Antibiotics are classified as their chemical structures and the mechanism of inhibition of microorganisms and they can be divided into subgroups such as $\beta$-lactams, quinolones, tetracyclines, macrolides, sulfonamides and others. The active compounds of antibiotics are often complex molecules, which may have different functionalities. In the environment, these molecules could be found as neutral, cationic, anionic, or zwitterionic forms. Because of the 
different functionalities within one molecule, their physicochemical and biological properties may change with $\mathrm{pH}$ levels [17].

\subsection{Sulfamethoxazole}

In this chapter, sulfamethoxazole (SMX) is selected as model compound. The systematic name of this compound is 4-amino- $N$-(5-methylisoxazol-3-yl)-benzenesulfonamide. Sulfamethoxazole and other sulfonamides have a similar structure to $p$-aminobenzoic acid and inhibit to the synthesis of nucleic acids in sensitive microorganisms by blocking the conversion of $p$ aminobenzoic acid to the coenzyme dihydrofolic acid, a reduced form of folic acid; dihydrofolic acid is obtained from dietary folic acid so sulfanomides do not have any influence on human cells. Their action is primarily bacteriostatic, although they may be bactericidal where concentrations of thymine are low in surrounding medium. The sulfonamides have a broad spectrum of action, but the development of widespread resistance has greatly reduced their usefulness, and susceptibility often varies widely even among nominally sensitive pathogens like Gram-positive and Gram-negative cocci.

There are several mechanisms of resistance including alteration of dyhydropteroate synthetase, the enzyme inhibited by sulfonamides, to a less sensitive form, or an alteration in folate biosynthesis to an alternative pathway; increased production of $p$-aminobenzoic acid; or decreased uptake or enhanced metabolism of sulfonamides.

Resistance may result from chromosomal alteration, or may be plasmid-mediated and transferable, as in many resistant strains of enterobacteria. High-level resistance is usually permanent and irreversible. There is complete cross-resistance between the different sulfonamides [18].

\subsection{Consumption and occurrence}

The yearly consumption of antibiotics worldwide is estimated between 500 tons [19]. Approximately $90 \%$ of the consumed antibiotics are excreted via urinary or fecal pathways from the human body after partial or no metabolism and they are transferred to the domestic sewage plants or directly to the environment. Conventional biological treatment of domestic sewage provides very low or no reduction for these compounds, which usually by-pass treatment and accumulate in the receiving waters.

Antibiotic consumption changes depending on the country and/or region however the situation is scarce and heterogenous. Country specific consumption for groups of antibiotics in DDDs can be found for Europe on the ESAC homepage [20]. Using patterns of different regions and countries are given Table 1 . The relative importance of the different use patterns in different countries is still not known.

An increasing number of studies have been done to determine the source, occurrence, fate, and effects on the ecosystem of antibiotics. However, there is still a lack of understanding and knowledge of these compounds. So studies maybe focus on the strategies about stream segregation and at-source treatment of the concentrated streams appears. 


\begin{tabular}{|c|c|c|c|c|c|c|c|}
\hline $\begin{array}{l}\text { Region/ } \\
\text { Country }\end{array}$ & $\begin{array}{l}\text { Total } \\
\text { volume } \\
\text { used in } \\
\text { human } \\
\text { medicine } \\
\text { (ton/year) }\end{array}$ & $\begin{array}{l}\text { Volume used } \\
\text { in human } \\
\text { medicine } \\
\text { (gram per } \\
\text { capita) }\end{array}$ & $\begin{array}{l}\text { Thereof in } \\
\text { hospitals } \\
\text { (\%) }\end{array}$ & $\begin{array}{c}\text { Unuse } \\
\text { medicaments }\end{array}$ & $\begin{array}{l}\text { Measured } \\
\text { in sewage } \\
\text { up to }(\mu \mathrm{g} / \mathrm{L})\end{array}$ & $\begin{array}{l}\text { Measured } \\
\text { in surface } \\
\text { water up to } \\
\qquad(\mu \mathrm{g} / \mathrm{L})\end{array}$ & Reference \\
\hline World wide & $\begin{array}{c}100000-200 \\
000\end{array}$ & N.D. & N.D. & N.D. & N.D. & N.D. & [19] \\
\hline \multicolumn{8}{|l|}{ EU } \\
\hline+ & 8367 & 22.4 & N.D. & N.D. & N.D. & N.D. & [21] \\
\hline \multicolumn{8}{|l|}{ Switzerland } \\
\hline USA & 4860 & 17 & 70 & N.D. & 1.9 & 0.73 & {$[22,23]$} \\
\hline Canada & N.D. & N.D. & N.D. & N.D. & N.D. & 0.87 & [24] \\
\hline Switzerland & 34.2 & 4.75 & $20-40$ & N.D. & 0.57 & 0.2 & [25] \\
\hline Germany & 411 & 4.95 & 25 & $20-40$ & 6 & 1.7 & {$[16,26]$} \\
\hline Denmark & 40 & 7.4 & N.D.b & N.D. & 5N.D. & N.D. & [27] \\
\hline Austria & 38 & 4.7 & N.D. & $20-30$ & N.D. & N.D. & [28] \\
\hline Netherlands & 40.9 & 3.9 & 20 & N.D. & 4.4 & $0.11-0.85$ & [29] \\
\hline Italy & 283 & 4.88 & N.D. & N.D. & $0.85-$ & 0.25 & [30] \\
\hline Turkey & N.D. & 31.4 & N.D. & N.D. & N.D. & N.D. & [31] \\
\hline
\end{tabular}

Table 1. Country specific antibiotics consumption and occurrence data (N.D.: not defined)

\subsection{Production and manufacturing}

Pharmaceutical industries have minor importance on the sewage treatment plants. Only in some Asian countries, wastewaters from this industry contributes to the sewage and cause an increase in the concentration of single compound up to $\mathrm{mg} / \mathrm{L}$ level [32, 33, 34]. Also in developed countries, manufacturing plants increases the total antibiotic concentrations in the domestical wastewater [35].

The main problem for this industry is that they still use the physicochemical treatment technologies in the plant to remove the compounds from their wastewater. However, this approach is expensive.

\subsection{Elimination and treatment}

In the literature, there are lots of studies focused on the fate of these compounds in conventional domestical wastewater treatment plants and also lab-scale applications in the innovative treatment methods. Elimination and/or treatment of these organic compounds are the results of biotic and abiotic processes. While biotic process is the biodegradation by microorganisms, abiotic processes are sorption, hydrolysis, oxidation-reduction, and photolysis.

\subsubsection{Sorption}

Before to assess the sorption characteristics of antibiotics, it is necessary to consider their physical and chemical parameters. Tolls [36] investigated the sorption behavior of these 
compounds in soil and the results showed that sorption mechanism of antibiotics could be very complex and difficult.

Additionally, binding to particles or the formation of complexes may prevent their detection. For example, tetracyclines are able to form complexes with double cations such as magnesiumor calcium [37]. Also humic substances cause the change in the surface properties and sites available for sorption and reactions. Gu and Karthikeyan [38] reported that there is a strong interaction between humic acids, hydrous $\mathrm{Al}$ oxide and tetracycline. Some studies showed that antibiotics used in medicine such as fluoroquinolones and macrolides can reach the terresrial environment by sewage sludge [38, 39].

Also sorption mechanism is a significant process for sulphonamides [36]. However, knowledge about the interaction of antibiotics with sludge and of sediments with sludge in activated sludge plants as well as the subsequent potential for their release back into the environment is still too sparse.

\subsubsection{Photolysis}

Photochemical process can be important in the surface waters and treatment plant effluents as another elimination process [40-43]. In the environment, photolysis process is not effective in turbid water or river and lakes, which are shadowed. So, the in the lab-scale experiments cannot reflect the photochemical process in the nature. Also, effectiveness of depletion process can differ under different environmental conditions such as $\mathrm{pH}$, temperature, water hardness [44] and depends on type of matrix, location, season, latitude [45].

One of the problems about this type of process is that incomplete photo-transformation and photo-degradation can cause to more or less stable or toxic compounds although this does not necessarily have to happen [46-48].

The significance and extent of direct and indirect photolysis of antibiotics in the aquatic environment are different for each compound because some of them are light sensitive (e.g. quinolones, tetracyclines, sulphonamides, tylosin, nitrofuran antibiotics). However, not all compounds are photo-degradable [49]. Tetracyclines are senstive to photo-degradation. Samuelsen [50] investigated the sensitivity of oxytetracycline towards light in seawater as well as in sediments. The antibiotics proved to be stable in sediments rather than in seawater. As no mechanism of decomposition other than photolysis is known for them [51], the substance remains in the sediment for a long period, as shown by [52]. Boree et al. [53] showed that sulphanilic acid was found as a degradation product common to most of the sulpha drugs.

\subsubsection{Hydrolysis and thermolysis}

Another important pathway for the non-biotic decomposition of organic substances in the environment is hydrolysis. Some instability in water could be demonstrated for some tetracycylines [54]. In general, the hydrolysis rates for oxytetracycline increase with reascept to temperature at $\mathrm{pH}$ 7. The half-lives of oxytetracycline under investigation changed by differences in temperature, light intensity and flow rate from one test tank to another. However sulphonamides and quinolones are known as resistant antibiotic to hydrolysis. 


\subsubsection{Oxidation}

Pharmaceutical industry wastewaters including antibiotic are well known for the difficulty of their elimination by conventional biological treatment methods and their important contribution to environmental pollution is due to their fluctuating and recalcitrant nature. For this reason, oxidation processes are usually applied.

The presence of carbon-carbon double bonds, aromatic bonds or nitrogen is a necessary essential for this application. However, the presence of these structural elements does not provided the fast and full degradation or even the complete degradation.

The effect of ozonation on the degradation of oxytetracycline in aqueous solution at different $\mathrm{pH}$ values (3, 7 and 11) was reported by Li et al. [55]. The study was designed that ozonation as a partial step in a combined treatment concept is a potential technique for biodegradability enhancement. It has been shown that COD removal rates increase with increasing $\mathrm{pH}$ as a consequence of enhanced ozone decomposition rates at elevated $\mathrm{pH}$ values. The results of bioluminescence data indicate that the initial by-products after partial ozonation (5-30 min) of oxytetracycline were more toxic than the parent compound [55].

Sulfamethoxazole was also efficiently degraded by ozonation [56]. An improvement in biodegradability by the increasing of BOD5/COD ratio from 0 to 0.28 was observed by the authors after $60 \mathrm{~min}$ of ozonation. The acute toxicity of the intermediates was checked and a slight acute toxicity increment in the first stage of ozonation was found. $\mathrm{pH}$ variation was found as important parameter on TOC and COD removal efficiencies. The complete sulfamethoxazole removal was achieved for an in photo-Fenton process [57]. Toxicity and inhibition tests pointed in the same direction: no toxic effect of oxidized intermediates was determined and also no inhibition was detected on activated sludge activity.

\subsubsection{Biodegradation}

Biodegradability of most antibiotics has been checked and it was found that they are not biodegradable under aerobic conditions until today [3, 11, 55, 58, 59]. Biodegradability characteristics have been weak for most of the compounds investigated in laboratory tests such as the OECD test series $(301-303,308)$ - even for some of the ß-lactams (Alexy et al., 2004). Out of 16 antibiotics tested, only benzyl penicillin (penicillin G) was completely mineralized in a combination test (combination of the OECD 302 B and OECD 301 B tests; [11]).

Biodegradation for tetracycline was not observed during a biodegradability test (sequence batch reactor), and sorption was found to be the principal removal mechanism for tetracycline in activated sludge [61].

Some antibiotics occurring in soil and sediment proved to be quite persistent in laboratory testing as well as in field studies. Some of them were not biodegradable also under anaerobic conditions [12] others did [62]. Substances extensively applied in fish farming had long half-lives in soil and sediment, as reported in several investigations [63]; [64]; [65]; [66]; [67]; [68]; [69]). However, some substances were at least partly degradable ([70]; [71]; [72], [66]; [68]; [73]). Maki et al. [62] found that ampicillin, doxycycline, oxytetracy- 
cline, and thiamphenicol were significantly degraded, while josamycin remained at initial levels. Tylosin was biodegraded [42].

\subsection{Problem definition and aim}

The yearly consumption of antibiotics is 500 tons throughout the world according to the data of 2001. Approximately $90 \%$ of the consumed antibiotics after being partially metabolized or not being metabolized are excreted by the help of urea or feces from the body and transferred to the domestic sewage plants. These antibiotics are discharged into the receiving environment with no or low elimination after being treated in conventionally operated domestic sewage plants. While the concentration of these materials in domestic wastewaters and surface waters are in $\mu \mathrm{g} / \mathrm{l}$ level, in pharmaceutical wastewater they are in 100-1000 mg/L level [74, 75, 76, 77]. As this low concentration in the surface wastewaters cause important problems in the ecosystem, it necessitates the removal of high antibiotic amount that are found in the pharmaceutical wastewaters. However, because the chemical removals of these materials are costly, biological treatment is essential. Antibiotics are the one of these compounds and the most often discussed pharmaceuticals because of their potential role in the spread and maintenance of (multi)resistance of bacterial pathogens. There are lots of studies that have been done in Europe and North America on the detection and removal of antibiotics in the receiving environment and the treatment plant $[4,5,23,24,78-84]$. However, the studies on the treatability of these antibiotics biologically are quite few [61, 85]. Also the scope of the studies done on the biodegradability potential of these materials is limited [11, 12, 86, 87]. Additionally, the studies on the microbial groups and species that are responsible for degradation have not been done, yet.

In this scope, determination of biodegradation characteristics of the refractory compounds and their toxic/inhibition effects on microbial community is substantial for environmental engineering. For this aim, the biodegradability of these sulfamethoxazole under anoxic and anaerobic conditions and also changes in microbial groups under the different conditions are explained in this chapter.

\section{Materials and methods}

\subsection{Experimental approach}

This study involves setting-up batch biodegradation test to investigate biodegradation characteristics of sulfamethoxasole (SMX) under anoxic and anaerobic conditions. The biodegradation test bottles were set up under nitrate reducing conditions (NRC), sulfate reducing conditions (SRC) and methanogenic conditions (MC). Experiment was carried out for 120 days. During the experiment, gas production was monitored daily. Destructive sampling was done in four different times (at $0^{\text {th }}, 20^{\text {th }}, 60^{\text {th }}$ and $120^{\text {th }}$ day). Wet chemical analysis (dissolved organic carbon [DOC], SMX measurements and electron acceptor measurements) and microbiological analysis (quantitative real-time PCR [Q-PCR]) were carried for four sampling times. 


\subsection{Set-up of batch biodegradation test bottles}

In this study, two different seed sludges were used for setting-up of the batch tests. For NRC, the seed was taken from anoxic part of a domestic wastewater treatment plant in Istanbul whereas; test tubes for the SRC and MC were inoculated by anaerobic sludge from a full-scale UASB reactor treating alcohol distillery effluents.

The batch tests were constructed in $120 \mathrm{~mL}$ serum bottles, $100 \mathrm{~mL}$ of active volume, according to modified OECD 311 protocol [13]. The constituents of each experimental set for NRC, SRC and MC conditions are given in Table 2, 3 and 4, respectively. Also chemicals of the trace element solution and their amounts are given in Table 5. SMX was chosen as the model carbon source. The test tubes were set up as duplicates including positive and negative controls. Phenol was chosen as slowly biodegradable carbon source for positive control set. Negative control sets were constructed without any carbon source to determine endogenous decay. All sets were set-up in an anaerobic cabinet (Coy Laboratory Products, U.S.).

Experimental sets were destructed in 4 different sampling times. The first set was destructed immediately after all the test tubes were set-up, the other three sets were spoiled in day 20, day 60 and day 120. In each test tube, after inoculation $2000 \mathrm{mg} / \mathrm{L}$ TVS was maintained. Phenol and SMX concentrations were adjusted to $80 \pm 4.5 \mathrm{mg}$ DOC/L and $280 \pm 1.0 \mathrm{mg}$ DOC/L within the all experimental groups. The dissolved organic carbon (DOC) value of negative control bottles was $18.6 \pm 1.5 \mathrm{mg} / \mathrm{L}$. All solutions were deoxygenated and adjusted to $\mathrm{pH} 7$. Biodegradation test bottles were incubated at $20^{\circ} \mathrm{C}$ and $35^{\circ} \mathrm{C}$ for NRC and MC/SRC, respectively. All test bottles were stored at dark chambers to ensure occurring only biodegradation and sorption mechanisms during the experiment. The test tubes were shaken daily by hand.

\begin{tabular}{cc}
\hline CONSTITUENT & AMOUNT (g) \\
\hline Anhydrous potassium dihydrogen phosphate (KH2PO4) & 0,27 \\
\hline Ammonium chloride (NH4Cl) & 1,12 \\
\hline Potassium Nitrate (KNO3) & 0,53 \\
\hline Calcium chloride dihydrate (CaCl2.2H2O) & 1 \\
\hline Magnesium chloride hexahydrate (MgCl2.6H2O) & 0,075 \\
\hline Iron (II) chloride tetrahydrate (FeCl2.4H2O) & 0,1 \\
\hline Resazurin (oxygen indicator) & 0,02 \\
\hline Stock solution of trace elements & 0,001 \\
\hline Add de-oxygenated water & 0,1 \\
\hline
\end{tabular}

Table 2. Medium for nitrate reducing conditions (10 $\mathrm{mM}$ potassium nitrate) 


\begin{tabular}{cc}
\hline CONSTITUENT & AMOUNT (g) \\
\hline Anhydrous potassium dihydrogen phosphate $(\mathrm{KH} 2 \mathrm{PO} 4)$ & 0,27 \\
\hline Disodium hydrogen phosphate dodecahydrate $(\mathrm{Na2HPO} 4.12 \mathrm{H} 2 \mathrm{O})$ & 1,12 \\
\hline Ammonium chloride $(\mathrm{NH} 4 \mathrm{Cl})$ & 0,53 \\
\hline Potassium Sulfate $(\mathrm{K} 2 \mathrm{SO} 4)$ & 1,8 \\
\hline Calcium chloride dihydrate $(\mathrm{CaCl} 2.2 \mathrm{H} 2 \mathrm{O})$ & 0,075 \\
\hline Magnesium chloride hexahydrate $(\mathrm{MgCl} 2.6 \mathrm{H} 2 \mathrm{O})$ & 0,1 \\
\hline Iron (II) chloride tetrahydrate $(\mathrm{FeCl} 2.4 \mathrm{H} 2 \mathrm{O})$ & 0,02 \\
\hline Resazurin (oxygen indicator) & 0,001 \\
\hline Sodium sulphide nonahydrate (Na2S.9H2O) & 0,1 \\
\hline Stock solution of trace elements & $10 \mathrm{ml}$ \\
\hline Add de-oxygenated water & to 1 liter
\end{tabular}

Table 3. Medium for sulfate reducing conditions ( $10 \mathrm{mM}$ potassium sulfate)

\begin{tabular}{cc}
\hline CONSTITUENT & AMOUNT $(\mathbf{g})$ \\
\hline Anhydrous potassium dihydrogen phosphate $(\mathrm{KH} 2 \mathrm{PO} 4)$ & 0,27 \\
\hline Disodium hydrogen phosphate dodecahydrate $(\mathrm{Na2HPO} 4.12 \mathrm{H} 2 \mathrm{O})$ & 1,12 \\
\hline Ammonium chloride $(\mathrm{NH} 4 \mathrm{Cl})$ & 0,53 \\
\hline Calcium chloride dihydrate $(\mathrm{CaCl} 2.2 \mathrm{H} 2 \mathrm{O})$ & 0,075 \\
\hline Magnesium chloride hexahydrate $(\mathrm{MgCl} 2.6 \mathrm{H} 2 \mathrm{O})$ & 0,1 \\
\hline Iron (II) chloride tetrahydrate $(\mathrm{FeCl} 2.4 \mathrm{H} 2 \mathrm{O})$ & 0,02 \\
\hline Resazurin (oxygen indicator) & 0,001 \\
\hline Sodium sulphide nonahydrate (Na2S.9H2O) & 0,1 \\
\hline Stock solution of trace elements & $10 \mathrm{ml}$ \\
\hline Add de-oxygenated water & to 1 liter
\end{tabular}

Table 4. Medium for methanogenic conditions

\begin{tabular}{cc}
\hline CONSTITUENT & AMOUNT \\
\hline Manganese chloride tetrahydrate $(\mathrm{MnCl} 2.4 \mathrm{H} 2 \mathrm{O}) 50 \mathrm{mg}$ & $50 \mathrm{mg}$ \\
\hline Boric acid (H3BO3) & $5 \mathrm{mg}$ \\
\hline Zinc chloride $(\mathrm{ZnCl} 2)$ & $5 \mathrm{mg}$ \\
\hline Copper (II) chloride $(\mathrm{CuCl} 2)$ & $3 \mathrm{mg}$ \\
\hline Disodium molybdate dihydrate $(\mathrm{Na} 2 \mathrm{MoO} 4.2 \mathrm{H} 2 \mathrm{O})$ & $1 \mathrm{mg}$ \\
\hline Cobalt chloride hexahydrate $(\mathrm{CoCl} 2.6 \mathrm{H} 2 \mathrm{O})$ & $100 \mathrm{mg}$ \\
\hline Nickel chloride hexahydrate $(\mathrm{NiCl} 2.6 \mathrm{H} 2 \mathrm{O})$ & $10 \mathrm{mg}$ \\
\hline Disodium selenite (Na2SeO3) & $5 \mathrm{mg}$ \\
\hline Add de-oxygenated water & to $1 \mathrm{liter}$
\end{tabular}

Table 5. Stock solution of trace elements 
Headspace pressure was measured by hand-held pressure transducer (Lutron PM-9107, U.S.A.) every day. At each sampling time, biogas composition of the samples was determined via gas chromatography (Perichrom, France). DOC concentration of each sample was measured by Shimadzu ASI-V TOC analyser (Japan). Nitrate and sulfate concentrations were measured by DIONEX ICS 1500 ion chromatograph (U.S.A.). SMX measurements within the solid and liquid phase were carried by the protocol that is proposed previously by Karci and Balc1oglu [88].

\subsection{Calculation of mass balances}

Theoretical $\mathrm{CO}_{2}$ (Th $\mathrm{CO}_{2}$ ) and Theoretical biogas (Th biogas), which were used for evaluation of biodegradation, were calculated according DOC, gas and ion chromatography results. Mass balances were calculated by the assumptions, which were described by Ritmann and Mc Carty [89]. Simplified mass balances were given in Equation 1-3 for NRC, SRC and MC, respectively.

$$
\begin{gathered}
\mathrm{SMX}+\mathrm{NO}_{3}^{-} \rightarrow \text { Biomass }+\mathrm{CO}_{2}+\mathrm{N}_{2}+\mathrm{H}_{2} \mathrm{O} \\
\mathrm{SMX}+\mathrm{SO}_{4}{ }^{2-} \rightarrow \text { Biomass }+\mathrm{CO}_{2}+\mathrm{H}_{2} \mathrm{~S}+\mathrm{HS}^{-}+\mathrm{H}_{2} \mathrm{O} \\
\mathrm{SMX}+\mathrm{H}_{2} \mathrm{O} \rightarrow \text { Biomass }+\mathrm{CO}_{2}+\mathrm{CH}_{4}
\end{gathered}
$$

Ultimate biodegradation ratios were estimated by comparison of $\mathrm{ThCO}_{2}$ and $\mathrm{Th}$ biogas production (which were assumed to be produced as a result of $100 \%$ biodegradation of tetracycline) were compared to actual $\mathrm{CO}_{2}$ and biogas production within the batch tests, $\mathrm{DOC}$ elimination and SMX measurements.

\subsection{Microbiological analyses}

Genomic DNA (GDNA) was extracted from $0.5 \mathrm{~g}$ sludge using the Fast DNA Spin Kit for Soil (Qbiogene Inc., U.K.) following the manufacturer's instructions.

Q-PCR procedure recommended by Roche was followed and a Light Cycler Master Kit (Roche, Applied Science, Switzerland) was used to set up the reaction $(2.0 \mu \mathrm{l}$ master mix, $1.6 \mu \mathrm{l}$ $\mathrm{MgCl}_{2} 1.0 \mu \mathrm{l}$ Primer F and $\mathrm{R}, 13.4 \mu \mathrm{l}$ 2O, $1 \mu \mathrm{l}$ sample). Absolute quantification analysis of the GDNA was carried out with a Light Cycler 480 Instrument (Roche Applied Science, Switzerland). Primers used in the quantification are given in Table 6.

Significant differences were determined according to independent sample t-test. Pearson correlation was used for the interactions between variables. All the statistical analyses were conducted by using SPSS (IBM, U.S.A) and $\mathrm{p}<0.05$ level was used for significance. 


\begin{tabular}{|c|c|c|c|c|}
\hline Primer & Target Gene & $\begin{array}{c}\text { Target } \\
\text { Microorganisms }\end{array}$ & $\begin{array}{l}\text { Respiration } \\
\text { Conditions }\end{array}$ & References \\
\hline $\begin{array}{l}\text { Bac519f } \\
\text { Bac907r }\end{array}$ & $16 \mathrm{~S}$ rRNA & Bacteria & All & 90 \\
\hline $\begin{array}{l}\text { Arc349f } \\
\text { Arc806r }\end{array}$ & $16 \mathrm{~S}$ rRNA & Archaea & All & 91 \\
\hline$\frac{\text { Met348f }}{\text { Met786r }}$ & 16S rRNA & Methanogens & All & 92 \\
\hline DSRp2060F & $\begin{array}{l}\text { Sulfites reductase } \\
\text { beta sub-unit (dsrB) }\end{array}$ & $\begin{array}{c}\text { Sulfate Reducing } \\
\text { Bacteria }\end{array}$ & $\begin{array}{l}\text { Only sulfate } \\
\text { reducing condition }\end{array}$ & 93 \\
\hline
\end{tabular}

Table 6. Primers and target groups for Q-PCR analysis

\section{Results and discussion}

\subsection{Methane generation}

Biogas generation in the test bottles operated under sulphate reducing and methanogenic conditions was observed daily. However methane content of the biogas in the test bottles were determined in each sampling time before the destruction of the test bottles as $0^{\text {th }}, 20^{\text {th }}, 60^{\text {th }}$ and $120^{\text {th }}$ days. Produced methane volume in sulfamethoxazole (SMX) and reference item (REF) fed bottles with non-carbon source (NC) fed bottles under sulphate reducing and methanogenic conditions were given in Figure 1 and 2, respectively.

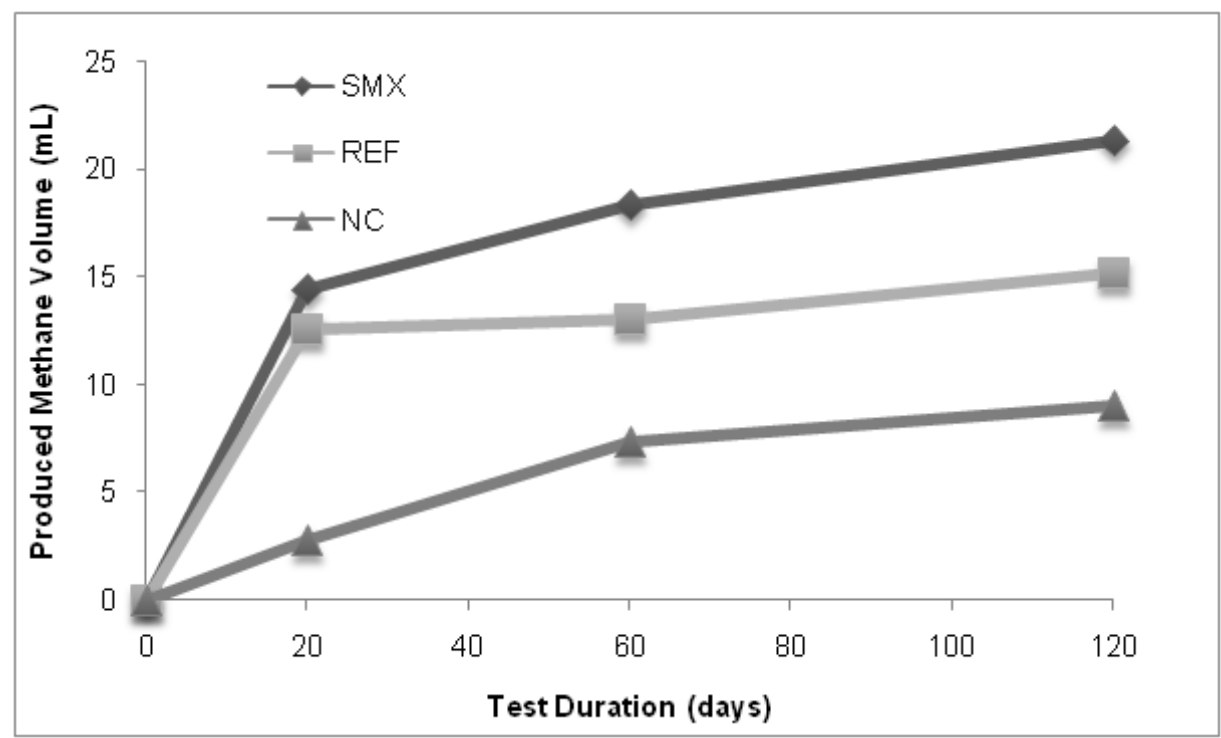

Figure 1. Methane production under sulfate reducing conditions 
As seen in Figure 1, the maximum methane production associated with SMX was $21 \mathrm{~mL}$ while the maximum values were determined as $15 \mathrm{~L}$ and $9 \mathrm{~mL}$ in REF and NC test bottles, respectively, under sulphate reducing conditions. These values increased to $132 \mathrm{~mL}, 41 \mathrm{~mL}$ and $23 \mathrm{~mL}$, respectively. This wide difference is expected as a result of sulphate inhibitory effect on methanogens. Another point to show the inhibition that most of the methane was produced during first 20 days under methanogenic conditions while methane production was slower under sulphate reducing conditions. Also it was known that sulphate reducers are much more versatile than methanogens and in environments where sulfate is present, sulfate-reducing bacteria compete with methanogenic consortia for common substrates. Compounds like propionate and butyrate, which require syntrophic consortia in methanogenic environments, are degraded directly by single species of sulfate reducing bacteria [94].

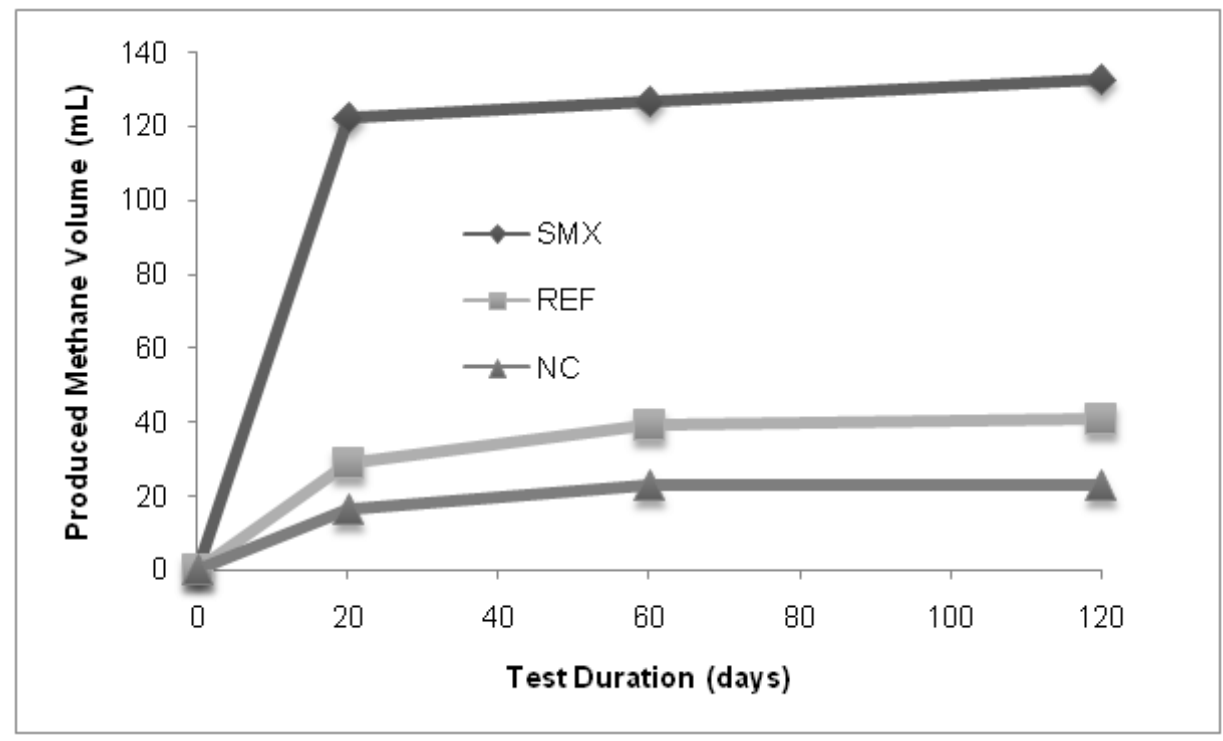

Figure 2. Methane production under methanogenic conditions

Positive and negative control groups were used to increase the reliability of the experiment. For positive control groups phenol was used as a carbon source. For all three electron-accepting conditions, phenol was biodegraded at the ratios between $74-78 \%$ in 120 days, which indicated the ultimate biodegradation according to OECD protocol [13]. Measured $\mathrm{CO}_{2}$ and biogas production within the negative control groups subtracted as blanks to reveal the actual biodegradation ratios. The $\mathrm{CO}_{2}$ productions in the negative control test bottles reached a total of $4-12 \mathrm{~mL}$ in 120 days corresponding to $70-100 \%$ of the theoretical $\mathrm{CO}_{2}\left(\mathrm{Th}^{\mathrm{CO}}\right)$ production while biogas production reached $40 \mathrm{~mL}$ corresponding to $100 \%$ of the Th biogas occurred via degradation of biomass completely. 


\subsection{Removal of dissolved organic carbon}

Total organic carbon parameter was used to compare the biodegradation capacity of the antibiotic and reference item under nitrate reducing, sulphate reducing and methanogenic conditions. Also electron acceptors were measured in the test bottles. DOC removal was higher in the first 60 days in all electron-accepting condition. The removal between $60^{\text {th }}-120^{\text {th }}$ days, any significant changes were not observed.

In Figure 3, DOC and nitrate concentration changes in respect to time are given. in the beginning of the experiment, nitrate concentration in each bottle was $250 \mathrm{mg} / \mathrm{L}$. This concentration decreased to less than $10 \mathrm{mg} / \mathrm{L}$ in the first 20-day period of the experiment. Also decrease in DOC values was parallel to nitrate concentration except of SMX test bottles. The decrease in the DOC continued first 60 days while nitrate concentration was $1 \mathrm{mg} / \mathrm{L}$.

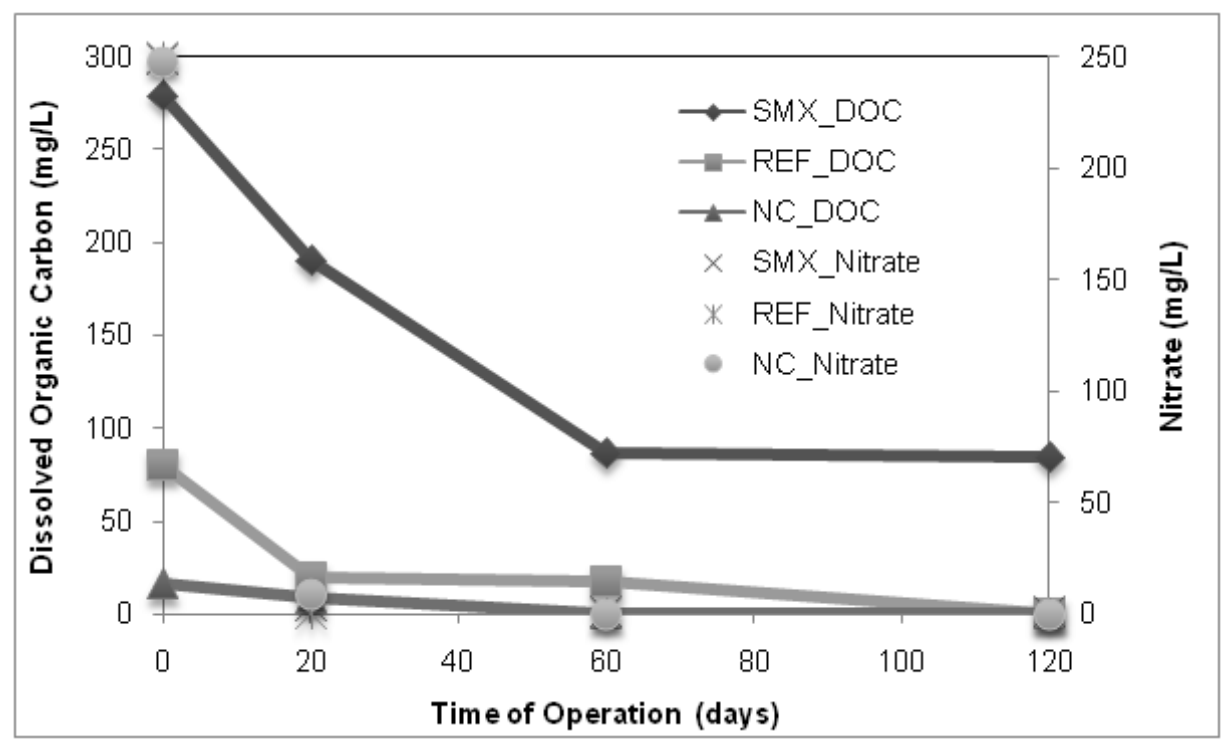

Figure 3. DOC and nitrate concentration in SMX, REF and NC bottles under nitrate reducing conditions

As seen in Figure 4, most of the DOC in the SMX bottle was consumed in the first 60 days. Also sulphate concentration decreased from $480 \mathrm{mg} / \mathrm{L}$ to $59 \mathrm{mg} / \mathrm{L}$ during same period.

In Figure 5, changes in DOC concentrations under methanogenic conditions are given. The results indicated that the removal of DOC mechanism was more quickly in the first 20 days. This pattern was also similar with the other respiration conditions. Also reference item was consumed in the same period. DOC concentration in SMX bottles decreased from $280 \mathrm{mg} / \mathrm{L}$ to $88 \mathrm{mg} / \mathrm{L}$ in the first 20 days. After this day, only $18 \mathrm{mg} / \mathrm{L} \mathrm{DOC}$ was consumed and the final DOC concentration in SMX test bottles was determined as $70 \mathrm{mg} / \mathrm{L}$. 


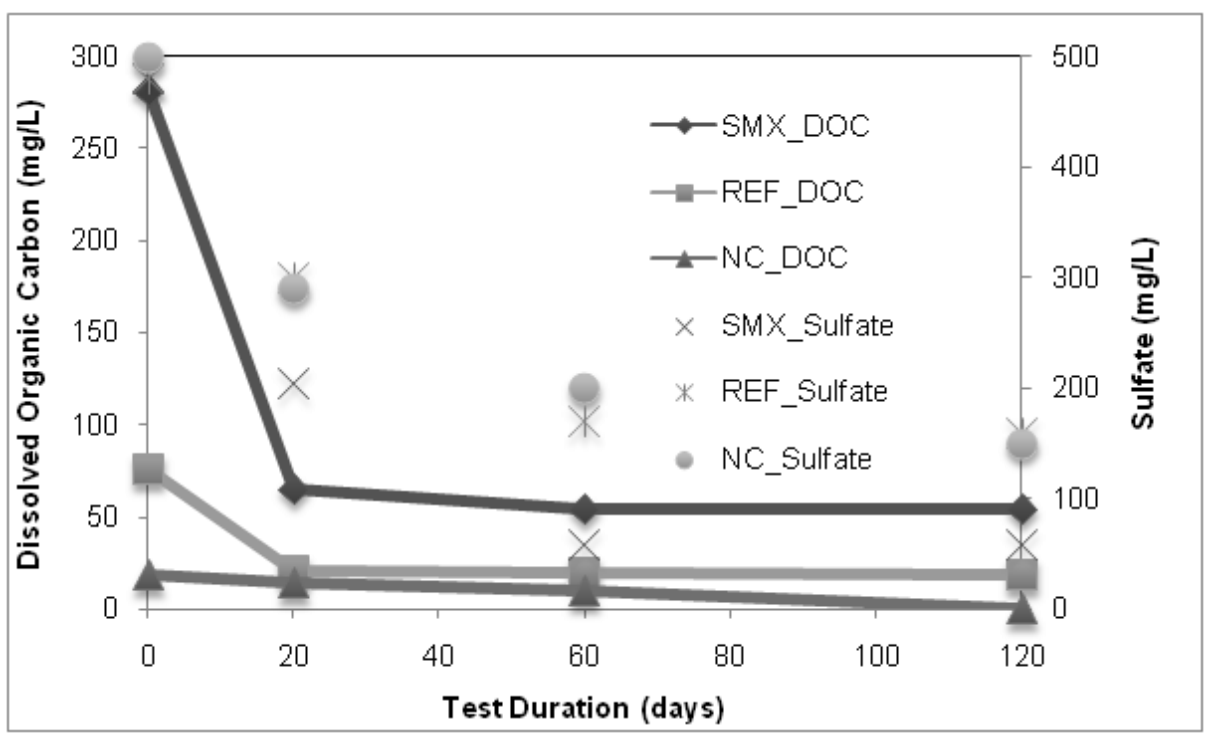

Figure 4. DOC and sulphate concentration in SMX, REF and NC bottles under sulphate reducing conditions

The most efficient DOC removal in SMX test bottles was observed under SRC and MC as 78/ and $74 \%$, respectively. Under NRC, DOC removal was detected as $71 \%$.

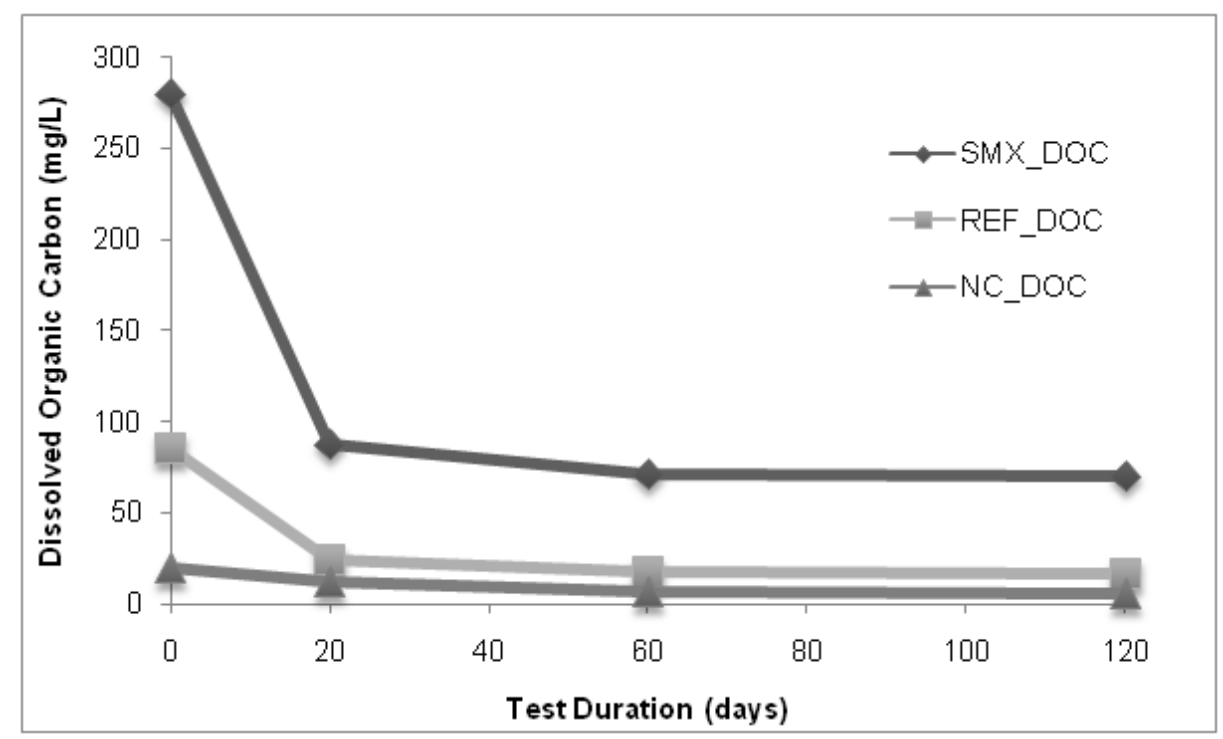

Figure 5. DOC concentration in SMX, REF and NC bottles under methanogenic conditions 
In another study showed that SMX affected the propionic acid degradation and acetic acid utilization pathways in the higher concentrations [95]. Sponza and Demirden [96] also showed while sulfamerazine, which is another antibiotic from sulfonamid group, was being fed to the anaerobic system, an increase in VFA accumulation was observed with respect to rising of antibiotic concentration. Decreased utilization of butyrate and propionate is consistent with the fact that these substrates are used directly by bacteria, homoacetogens. SMX also has a bacteriostatic inhibition effect on folic acid production of especially gram positive and negative cocci [18]. VFAs are not directly used by methanogens, however different groups of syntrophic bacteria use specific VFAs.

\subsection{Biodegradability of sulfamethoxazole and mass balance}

SMX measurement was done for water and sludge matrix. The recovery was found as $92 \%$ after solid-phase extraction (SPE). Antibiotic measurement in the sludge showed that the SMX concentration in the sludge did not change in respect to time and it is found as $50,4 \pm 3 \mathrm{mg} / \mathrm{L}$. This result indicated that velocity of biodegradation and sorption mechanisms are similar during the test. Antibiotic concentrations in water samples are given in Figure 6.

Antibiotic removal for three electro accepting conditions was same and it was detected as approx. $98 \%$ in water matrix. If the sorption mechanism takes into the consideration, the removal decreased to $70 \%$. Most of the antibiotic was removed in the first 60 days. There is no significant change between $60^{\text {th }}-120^{\text {th }}$ days. Also the decrease in electron acceptor concentration under nitrate reducing conditions may be caused a negative impact on microbial activity [97]. However, it was clear that antibiotic removal was faster under methanogenic conditions. The results showed that $68 \%$ of SMX was removed under methanogenic conditions while ultimate SMX removal was $70 \%$.

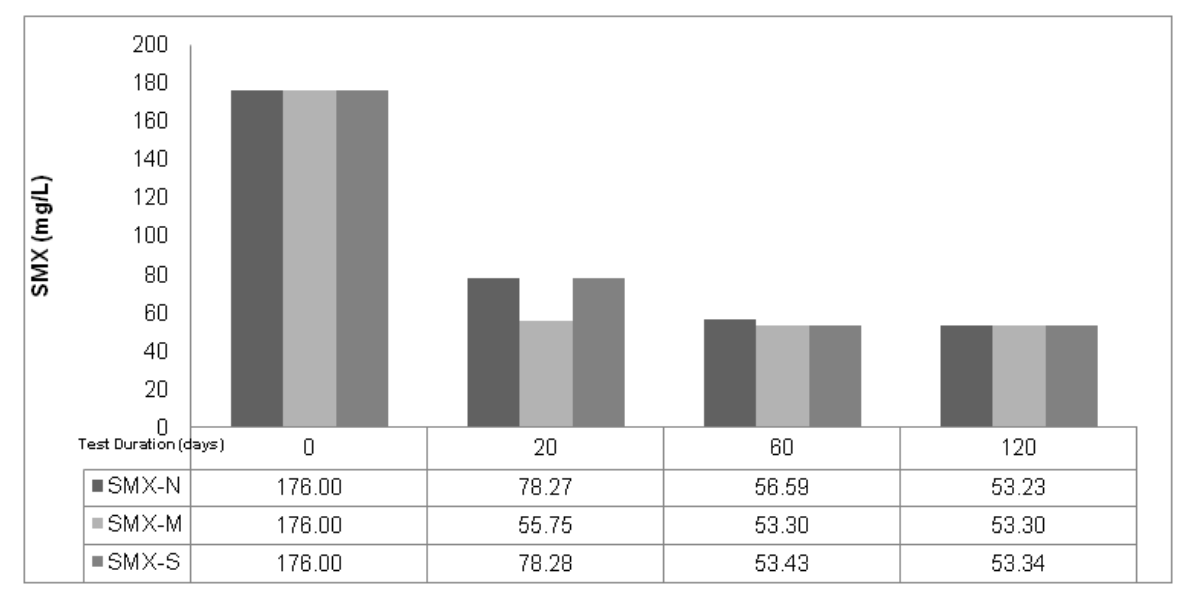

Figure 6. Sulfamethoxazole concentration under nitrate reducing (SMX-N), sulphate reducing (SMX-S) and methanogenic (SMX-M) conditions 
Figure 7 shows ultimate biodegradation ratios (evaluated according to gas production only derived from SMX biodegradation), sorption ratios according to SMX measurements within sludge and soluble microbial products (SP) and/or transformation products (TP) ratios that were calculated via DOC removal ratio compared with SMX biodegradation for each electron accepting condition throughout the operating period. SMX showed non-biodegradable behavior under SRC, NRC and MC according to OECD protocol [13].

SMX measurements within the sludge samples of the all experimental groups showed that $29 \%$ of the SMX sorbed to the solid media throughout the experiment time. Sorbed part of the SMX did not change for four sampling time. Stabile results indicated that sorption processes are more dominant rather than desorption processes since all serum bottles were shaken daily in order to increase the bioavailability of the carbon source. Yang et al. also confirmed the rapid sorption processes rather than biodegradation [10].

Under MC, biogas production showed that $23 \%$ of the SMX was mineralized. However, according to SMX and DOC measurements $40 \%$ of the SMX were removed from the liquid phase. This result indicated that parent compound transformed to SP and/or TP. $17 \%$ of the SMX was remained in liquid phase as its potential SP and/or TP. Gartiser et al. reported SMX as non-biodegradable compound (2.3\%) as well [11]. Different results of two studies mainly emanated by the application of different methods and duration time of the experiments.

Under SRC, $32 \%$ of the SMX was ultimately biodegraded whereas; $8 \%$ of the parent compound transformed to SP and/or TP. Under NRC, 38\% of the SMX was mineralized to $\mathrm{CO}_{2}$ and $2 \%$ of the SMX converted to residual SP and/or TP. Biodegradation ratios within the conventional treatment plants which is reported by Hong et al. [98] complies with our results. In their study $40 \%$ of the SMX removed from liquid phase. Also in our study, anoxic biodegradation rate was the highest removal rate among the experimental groups. Overall elimination within three electron-accepting conditions was calculated as $69 \%$.

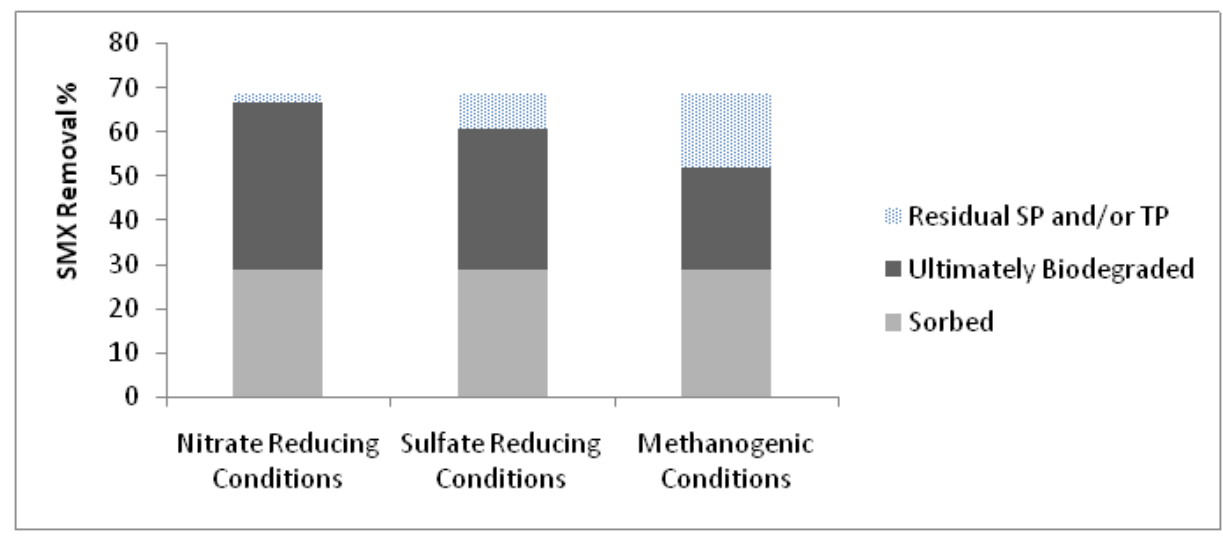

Figure 7. Biodegradation of SMX under different e-accepting conditions 


\subsection{Microbiological analyses}

Q-PCR analyses were carried out for four sampling times. Four different taxonomic groups were quantified. These were; Bacteria, Archaea, methanogenic Archaea and Sulfate Reducing Bacteria (SRB). There was no significant change in the amount of these populations during 120 days (data not shown). However, under methanogenic conditions, biogas, antibiotic concentration and microbial quantification data indicate that there was a strong correlation between antibiotic concentration and amount of bacterial and methanogenic species. This correlation was a strong proof of the usability of SMX and showed that the bacterial and archaeal community continued to work together while this compound was only carbon source. Figure 8 and Table 7 show the changes within these groups under methanogenic conditions and their correlations with each other, respectively.

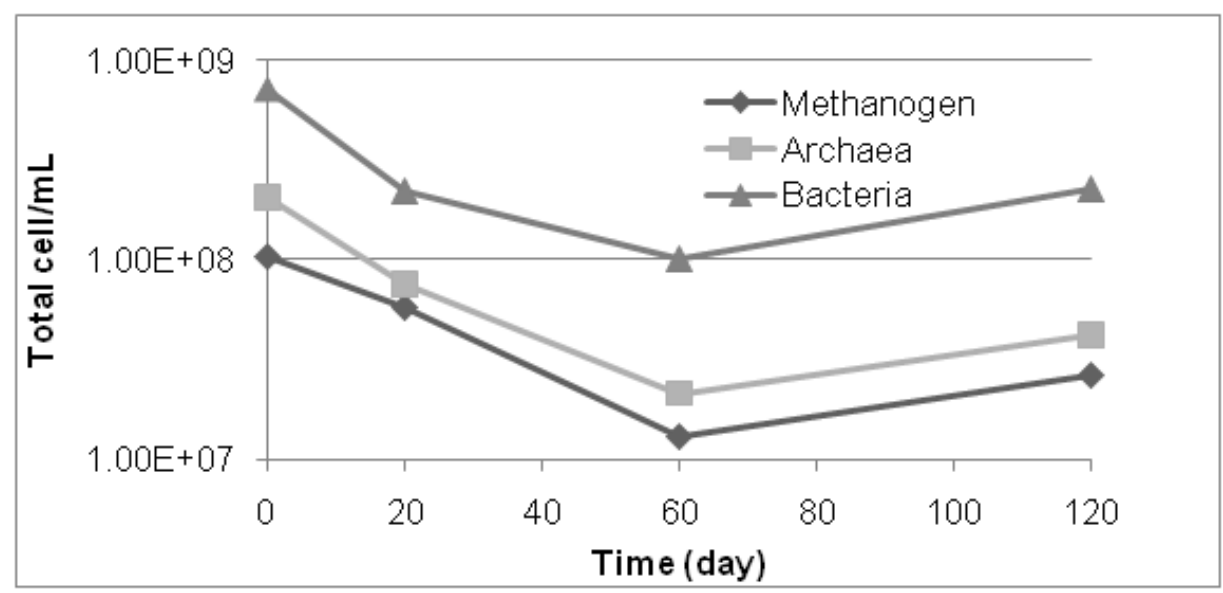

Figure 8. Microbial cell counts under methanogenic conditions

Table 7. Correlation analyses for methanogenic conditions $(n=3, p<0.05)$

As it can be seen in Table 7 for methanogenic conditions, there was a strong positive correlation between methanogenic count and bacterial count; also, they had a positive correlation with DOC and SMX concentration change over time. This observation shows that there may be syntrophic relationship between bacteria and methanogens in methanogenic conditions. In addition, SMX concentration is strongly correlated with bacterial and methanogenic count.

Insignificant change in microbial groups can be explained with two approaches. 1- SMX may have an inhibition on bacterial growth so SMX biodegradation delayed and microbial cells have faced with starvation as described by Gartiser et al. [12]. 2- Multi antibacterial resistant bacteria have been described by many authors [7, 99]. Based on that knowledge, bacterial populations in the batch tests might have gained resistance to SMX with time but would not able to use SMX efficiently. In this case, bacterial populations lowered their metabolic functions to survive rather than grow. Also changes in the population dynamics can be derived from 
the microbial interactions. Thus methanogens were not affected by SMX. Otherwise biogas production wouldn't have occurred or would have been inhibited because of their susceptibility to toxic compounds [100].

More detailed microbiological approach was applied in a parallel study [95]. The author tested the inhibition effect and biodegradability characteristic of same compound in long-term semicontinuous operation under anaerobic conditions. In that study, Clostiridum spp. was found in the system independently of operation time and SMX concentration in the system according to $16 \mathrm{~S}$ rDNA clone library and denaturing gradient gel electrophoresis (DGGE) studies. It was also expected due to they are responsible to fermentation and some species especially produce the ethanol. Additionally, Clostridium spp. have the role on the starch degradation by exoenzymes. Other OTUs, which were detected in the system, almost belong to the uncultured clones or unclassified bacterial cultured species. In addition to bacterial results, archaeal studies showed that acetoclastic methanogenic species disappeared in the last phases of operation in which SMX concentration increased. However the abundance of hydrogenotrophic methanogenswere higher than acetoclastic species and they were dominant during the operation.

Looking at this point, more detailed microbiological approach was needed to give the answers of two main questions: Which microbial groups are directly affected by SMX and which ones utilize this compound as a substrate? Next generation sequencing (NGS) based on DNA and also cDNA produced from total RNA represent more details about microbial community in each operation period. NGS is a novel sequencing technology for metagenomic studies. The main advantage of this technique is to sequence the mix GDNA directly without any preliminary study. By this means, the process does not cover the bias coming from polymerase chain reaction (PCR) and cloning. Additionally stable isotope probing (SIP) technique may be a good option to find the answer about which microbial groups utilize directly the SMX. In this technique, a labeled compound is given as substrate and then the produced GDNAs are monitored by labeled elements coming from utilized compound.

\section{Conclusion}

In the light of evaluations presented above, the significant findings of the study on the biodegradability characteristics of sulfamethoxazole under different electron accepting conditions may be outlined as follows:

The results suggested that the nature of the biodegradability characteristic of SMX are similar under nitrate reducing, sulphate reducing and methanogenic conditions and it was clear that biological treatment is suitable for this compound to remove from the wastewater during long retention times. However, methanogenic conditions should be selected because of obtaining biogas to use as energy source.

Microbial studies showed a syntrophic relationship between bacteria and methanogens in methanogenic conditions. Quantification of the main microbial groups has given general idea 
about the effect of SMX and showed the next step to clarify this mechanism: To focus microbial kinetics in terms of metabolic expressions on mRNA level and also quantification of antibiotic resistance genes in the system, which is operated under methanogenic conditions, give more information about the removal mechanism of this compound. Also for detailed information about microbial community and changes in the community, NGS is a good option. SIP is the direct method to observe which microbial species utilize the SMX and its transformation products.

\section{Acknowledgements}

This study was funded by The Scientific and Technological Research Council of Turkey (TUBITAK), Project No: 109Y012.

\section{Author details}

Zeynep Cetecioglu ${ }^{1}$, Bahar Ince ${ }^{2}$, Samet Azman ${ }^{1}$, Nazli Gokcek ${ }^{1}$, Nese Coskun ${ }^{1}$ and Orhan Ince

*Address all correspondence to: cetecioglu@itu.edu.tr

1 Istanbul Technical University, Environmental Engineering Department, Istanbul, Turkey

2 Bogazici University, Institute of Environmental Sciences, Istanbul, Turkey

\section{References}

[1] Li, B, \& Zhang, T. Biodegradation and adsorption of antibiotics in the activated sludge process. Environmental Science and Technology. (2011). , 44, 3458-3473.

[2] Xiao, Y, Chang, H, Jia, A, \& Hu, J Y. Trace analysis of quinolone and fluoroquinolone antibiotics from wastewaters by liquid chromatography electrospray tandem massspectrometry. Journal of Chromatography A, (2008).

[3] Kummerer, K. Pharmaceuticals in the Environment: Sources, Fate, Effects and Risks. 1st ed. Berlin, Springer-Verlag; (2001).

[4] Hirsch, R, Ternes, T, Haberer, K, \& Kratz, K L. Occurrence of antibiotics in the aquatic environment. Science of the Total Environment. (1999).

[5] Golet, E M, Strehler, A, Alder, A. C, \& Giger, W. Determination of fluoroquinolone antibacterial agents in sewage sludge and sludge-treated soil using accelerated sol- 
vent extraction followed by solid-phase extraction. Analytical Chemistry. (2002). , 74(21), 5455-5462.

[6] Andreozzi, R, Caprio, V, Ciniglia, C, \& De Champdore, M. Lo Giudice R, Marotta R, Zuccato E. Antibiotics in the environment occurrence in Italian STPs, fate, and preliminary assessment on algal toxicity of amoxicillin. Environmental Science and Technology. (2004). , 38(24), 6832-6838.

[7] Munir, M, Wong, K, \& Xagoraraki, I. Release of antibiotic resistant bacteria and genes in the effluent and biosolids of five wastewater utilities in Michigan. Water Science and Technology. (2011). , 45, 681-693.

[8] Nieto, A, Borrull, F, Pocurull, E, \& Marce, R M. Occurrence of pharmaceuticals and hormones in sewage sludge.Environmental Toxicological Chemistry.(2010). , 29(7), 1484-1489.

[9] Drillia, P, Dokianakis, S N, Fountoulakis, M S, Kornaros, M, Stamatelatou, K, \& Lyberatos, G. (2005). Journal of Hazardous Materials., 122, 259-265.

[10] Yang, S, Lin, C F, Lin, A Y, \& Hong, P A. Sorption and biodegradation of sulfonamide antibiotics by activated sludge: Experimental assessment using batch data obtained under aerobic conditions. Water Research.(2011). , 45, 3389-3397.

[11] Gartiser, S, Urich, E, Alexy, R, \& Kummerer, K. Anaerobic inhibition and biodegradation of antibiotics in ISO test schemes. Chemosphere. (2007). , 66, 1839-1848.

[12] Gartiser, S, Urich, E, Alexy, R, \& Kümmerer, K. Ultimate biodegradation and elimination of antibiotics in inherent tests. Chemosphere. (2007). , 67, 604-613.

[13] Anaerobic biodegradability of organic compounds in digested sludge- method by measurement of gas production (OECD 311)France; (2006). OECD- Organization for Economic Co-operation and Development.

[14] Korolkovas, A. (1976). Essentials of Medicine Chemistry. Wiley, New York.

[15] Foye, W. O, Lemke, T. L, \& Williams, D. A. (1995). Principles of Medicinal Chemistry. MD. Williams\&Wilkins, Baltimore.

[16] Kummerer, K, \& Henninger, A. (2003). Promoting resistance by the emission of antibiotics from hospitals and households into effluents. Clin. Microbiol. Infec. , 9, 1203-1214.

[17] Cunningham, V. (2008). Special characteristics of pharmaceuticals related to environmental fate. In. Kummerer, K. (Ed.), Pharmaceuticals in the Environment. Sources, Fate, Effects and Risk, third ed. Springer, Berlin Heidelberg, , 23-34.

[18] Sweetman, S. C. Ed.), (2009). Martindale. The complete drug reference, 36th edition. Pharmaceutical Press, London UK. 
[19] Wise, R. (2002). Antimicrobial resistance. priorities for action. J. Antimicrob. Chemoth., , 49, 585-586.

[20] http://www.esac.ua.ac.be/main.aspx?c=*ESAC2\&n=10661

[21] European Federation of Animal Health (FEDESA)(2001). Antibiotic use in farm animals does not threaten human health. FEDESA/FEFANA Press release, Brussels, 13 July.

[22] Union of Concerned Scientists(2001). Percent of all Antibiotics Given to Healthy Livestock. Press release, 8 January, Cambridge, MA

[23] Kolpin, D. W. Fur Kolpin long, E.T., Meyer, M.T., Thurman, E.M., Zaugg, S.D., Barber, L.B., Buxton, H.T., (2002). Pharmaceuticals, hormones, and others organic wastewater contaminants in U.S. streams, a national reconnaissance. Environ Sci Technol 36.1202-1211., 1999-2000.

[24] Miao, X. S, Bishay, F, Chen, M, \& Metcalfe, C. D. (2004). Occurrence of Antimicrobials in the final effluents of waste water treatment plants in Canada. Environ Sci Technol 38., 3533-3541.

[25] Kummerer, K. (2004). Pharmaceuticals in the Environment, Ed. Kummerer, K., 2nd Ed. Springer, Verlag.

[26] Rönnefahrt, I. (2005). Verbrauchsmengen in der Bewertung des Umweltrisikos von Humanarzneimitteln, In. Umweltbundesamt (Hrsg) Arzneimittel in der Umwelt- Zu Risiken und Nebenwirkungen fragen Sie das Umweltbundesamt. Dessau, UBA texte $29 / 05$.

[27] Kummerer, K. (2008). Antibiotics in the Environment. Pharmaceuticals in the Environment, Ed. Kummerer, K., 3rd Ed. Springer, Verlag., 3-35.

[28] Sattelberger, S. (1999). Arzneimittelruckstande in der Umwelt, Bestandsaufnahme und Problemstellung. Report des Umweltbundesamtes Österreich, Wien.

[29] Verbrugh, H. A, \& De Neeling, A. J. Eds, (2003). Consumption of antimicrobial agents and antimicrobial resistance among medically important bacteria in the Netherlands. SWAB NETHMAP.

[30] Calamari, D, Zuccato, E, Castiglioni, S, Bagnati, R, \& Fanelli, R. (2003). Strategic survey of therapeutic drugs in the rivers Po and Lambro in northern Italy, Environ Sci Technol., , 37, 1241-1248.

[31] Karabay, O. (2009). Türkiye'de antibiyotik kullanımı ve direnç nereye gidiyor?, ANKEM Dergisi, 23(2), 116-120.

[32] Larsson, D. G, De Pedro, C, \& Paxeus, N. (2007). Effluent from drug manufactures contains extremely high levels of pharmaceuticals. J. Hazard. Mater. , 148, 751-755. 
[33] Li, D, Yang, M, Hu, J, Ren, L, Zhang, Y, Chang, H, \& Li, K. (2008). Determination and fate of oxytetracycline and related compounds in oxyteracycline production wastewater and the receiving river. Environ. Toxicol. Chem., , 27, 80-86.

[34] Li, D, Yang, M, Hu, J, Zhang, Y, Chang, H, \& Jin, F. (2008). Determination of penicillin $\mathrm{G}$ and its degradation products in a penicillin production wastewater treatment plant and the receiving river. Water Res., , 42, 307-317.

[35] Thomas, K. V. (2008). The relevance of different point sources. Lecture given at the "First International Conference on Sustainable Pharmacy", April 2008, Osnabruck, Germany <http.//www.dbu.de/550artikel27307_135.html>., 24-25.

[36] Tolls, J. (2001). Sorption of veterinary pharmaceuticals in soils. a review. Environ. Sci. Technol., , 35, 3397-3406.

[37] Christian, T, Schneider, R. J, Färber, H. A, Skutlarek, D, Meyer, M. T, \& Goldbach, H. E. (2003). Determination of antibiotic residues in manure, soil, and surface waters, Acta Hydroch. Hydrob., , 31, 36-44.

[38] Gu, C, \& Karthikeyan, K. G. (2008). Sorption of the antibiotic tetracycline to humicmineral complexes. J. Environ. Qual. , 37, 704-711.

[39] Trivedi, P, \& Vasudevan, D. (2007). Spectroscopic investigation of ciprofloxacin speciation at the goethite-water interface. Environ. Sci. Technol., , 4, 3153-3158.

[40] Viola, G, Facciolo, L, Canton, M, \& Vedaldi, D. Dall'Acqua, F., Aloisi, G.G., Amelia, M., Barbafina, A., Elisei, F., Latterini, L., (2004). Photophysical and phototoxic properties of the antibacterial fluoroquinolones levofloxacin and moxifloxacin. Chem. Biodivers., , 1, 782-801.

[41] Werner, J. J, Chintapalli, M, Lundeen, R. A, Wammer, K. H, Arnold, W. A, \& Mcneill, K. (2007). Environmental photochemistry of tylosin. efficient, reversible photoisomerization to a less-active isomer, followed by photolysis. J. Agric. Food Chem., , 55, 7062-7068.

[42] Hu, D, \& Coats, J. R. (2007). Aerobic degradation and photolysis of tylosin in water and soil. Environ. Toxicol. Chem. , 26, 884-889.

[43] Hu, Z, Liu, Y, Chen, G, Gui, X, Chen, T, \& Zhan, X. (2011). Characterization of organic matter degradation during composting of manure-straw mixtures spiked with tetracyclines. Bioresource Technology, doi.j.biortech.2011.05.003.

[44] Werner, J. J, Arnold, W. A, \& Mcneill, K. (2006). Water hardness as a

[45] Kallenborn, R, Fick, J, Lindberg, R, Moe, M, Nielsen, K. M, Tysklind, M, \& Vasskog, T. (2008). Pharmaceutical residues in Northern European environments. consequences and perspectives. In. Kummerer, K. (Ed.), Pharmaceuticals in the Environment. Sources, Fate, Effects and Risk, third ed. Springer, Berlin-Heidelberg, , 61-74. 
[46] Arslan-alaton, I, \& Caglayan, A. E. (2006). Toxicity and biodegradability assessment of raw and ozonated procaine penicillin $\mathrm{G}$ formulation effluent, Ecotoxicol. Environ. Safe, , 63, 131-140.

[47] Gonzalez, O, Sans, C, \& Esplugas, S. (2007). Sulfamethoxazole abatement by photoFenton toxicity, inhibition and biodegradability assessment of intermediates. J. Hazard. Mater. , 146, 456-459.

[48] Paul, T, Miller, P. L, \& Strathmann, T. J. (2007). Visible-light-mediated TiO2 photocatalysis of fluoroquinolone antibacterial agents. Environ. Sci. Technol., , 41, 4720-4727.

[49] Turiel, E, Bordin, G, \& Rodríguez, A. R. (2005). Study of the evolution and degradation products of ciprofloxacin and oxolinic acid in river water samples by HPLC-UV/ MS/MS-MS. J. Environ. Monitor., , 7, 189-195.

[50] Samuelsen, O. B. (1989). Degradation of oxytetracycline in seawater at two different temperatures and light intensities, and the persistence of oxytetracycline in the sediment from a fish farm. Aquaculture, , 83, 7-16.

[51] Oka, H, Ikai, Y, Kawamura, N, Yamada, M, Harada, K, Ito, S, \& Suzuki, M. (1989). Photodecomposition products of tetracycline in aqueous solution.J. Agric. Food Chem., , 37, 226-231.

[52] Lunestad, B. T, \& Goksøyr, J. (1990). Reduction in the antibacterial effect of oxytetracycline in sea water by complex formation with magnesium and calcium. Dis. Aquat. Organ., , 9, 67-72.

[53] Boree, A. L, Arnold, W. A, \& Mcneill, K. (2004). Photochemical fate of sulfa drugs in the aquatic environment. sulfa drugs containing five-membered heterocycylic groups, Environ. Sci. Technol., , 38, 3933-3940.

[54] Halling-sørensen, B, Lykkeberg, A, Ingerslev, F, Blackwell, P, \& Tjørnelund, J. (2003). Characterisation of the abiotic degradation pathways of oxytetracyclines in soil interstitial water using LC-MS-MS. Chemosphere 50 (10), 1331-1342.

[55] Li, K, Yediler, A, Yang, M, Schulte-hostede, S, \& Wong, M. H. (2008). Ozonation of oxytetracycline and toxicological assessment of its oxidation by-products. Chemosphere, $72,473-478$.

[56] Dantas, R. F, Contreras, S, Sans, C, \& Esplugas, S. (2007). Sulfamethoxazole abatement by means of ozonation. J. Hazard Mater. , 150, 790-794.

[57] Gonzalez, O, Sans, C, \& Esplugas, S. (2007). Sulfamethoxazole abatement by photoFenton toxicity, inhibition and biodegradability assessment of intermediatesJ. Hazard. Mater. , 146, 456-459.

[58] Ingerslev, F, \& Halling-sørensen, B. (2001). Biodegradability of metronidazole, olaqiondox, and tylosin, and formation of tylosin degradation products in aerobic soil/ manure slurriesEcotoxicol. Environ. Safe , 48, 311-320. 
[59] Ingerslev, F, Torang, L, Loke, M. L, Halling-sørensen, B, \& Nyholm, N. (2001). Primary biodegradation of veterinary antibiotics in aerobic and anaerobic surface water simulation systems.Chemosphere , 44, 865-872.

[60] Gartiser, S, Urich, E, Alexy, R, \& Kuummerer, K. (2007). Ultimate biodegradation and elimination of antibiotics in inherent tests.Chemosphere, , 67, 604-613.

[61] Kim, S, Eichhorn, P, Jensen, J. N, Weber, A. S, \& Aga, D. S. (2005). Removal of antibiotics in wastewater. effect of hydraulic and solid retention timeson the fate of tetracycline in the activated sludge process. Environ. Sci. Technol., 39, 5816-5823.

[62] Maki, T, Hasegawa, H, Kitami, H, Fumoto, K, Munekage, Y, \& Ueda, K. (2006). Bacterial degradation of antibiotic residues in marine fish farm sediments of Uranouchi Bay and phylogenetic analysis of antibiotic-degrading bacteria using $16 \mathrm{~S}$ rDNA sequences. Fisheries Sci. , 72, 811-820.

[63] Jacobsen, P, \& Berglind, L. (1988). Persistence of oxytetracyline in sediment from fish farms. Aquaculture 70, 365-370.

[64] Hansen, P. K, Lunestad, B. T, \& Samuelsen, O. B. (1992). Effects of oxytetracycline, oxolinic acid and flumequine on bacteria in an artificial marine fish farm sediment. Can. J. Microbiol. , 38, 307-1312.

[65] Samuelsen, O. B, Torsvik, V, \& Ervik, A. (1992). Long-range changes in oxytetracycline concentration and bacterial resistance towards oxytetracycline in fish farm sediment after medication. Sci. Total Environ., , 114, 25-36.

[66] Samuelsen, O. B, Lunestad, B. T, \& Fjelde, S. (1994). Stability of antibacterial agents in an artificial marine aquaculture sediment studied under laboratory conditions. Aquaculture, , 126, 183-290.

[67] Hektoen, H, Berge, J. A, Hormazabal, V, \& Yndestad, M. (1995). Persistence of antibacterial agents in marine sediments. Aquaculture , 133, 175-184.

[68] Capone, D. G, Weston, D. P, Miller, V, \& Shoemaker, C. (1996). Antibacterial residues in marine sediments and invertebrates following chemotherapy in aquaculture, Aquaculture, , 145, 55-75.

[69] Marengo, J. R, Brian, O, Velagaleti, R. A, \& Stamm, R. R. J.M., (1997). Aerobic biodegradation of (14C)-sarafloxacin hydrochloride in soil. Environ. Toxicol. Chem., , 16, 462-471.

[70] Donoho, A. L. (1984). Biochemical studies on the fate of monensin in animals and in the environment. J. Anim. Sci. , 58, 1528-1539.

[71] Gilbertson, T. J, Hornish, R. E, Jaglan, P. S, Koshy, K. T, Nappier, J. L, Stahl, G. L, Cazers, A. R, Napplier, J. M, Kubicek, M. J, Hoffman, G. A, \& Hamlow, P. J. (1990). Environmental fate of ceftiofur sodium, a cephalosporin antibiotic. Role of animal excreta in its decomposition. J. Agric. Food Chem. , 38, 890-894. 
[72] Samuelsen, O. B, Solheim, E, \& Lunestad, B. T. (1991). Fate and microbiological effects of furazolidone in a marine aquaculture sediment. Sci. Total Environ., , 108, 275-283.

[73] Thiele-bruhn, S. (2003). Pharmaceutical antibiotic compounds in soils- a review. J. Plant. Nutr. Soil Sci., , 166, 145-167.

[74] Daughton, C. G, \& Ternes, T. A. (1999). Pharmaceuticals and personal care products in the environment. agents of subtle change? Environmental Health Perspectives, , 107, 907-938.

[75] Stuer-lauridsen, F, Birkved, M, Hansen, L. P, Lutzhoft, H. C. H, \& Halling-sorenson, B. (2000). Environmental risk assessment of human pharmaceuticals in Denmark after normal therapeutic use. Chemosphere, , 40, 783-793.

[76] Chelliapan, S, Wilby, T, \& Sallis, P. J. (2006). Performance of an upflow anaerobic stage reactor (UASR) in the treatment of pharmaceutical wastewater containing macrolide antibiotics, Water Res., 40 (3). , 507-516.

[77] Amin, M. M, Zilles, J. L, Greiner, J, Charbonneau, S, Raskin, L, \& Morgenroth, E. (2006). Influence of the antibiotic erythromycin on anaerobic treatment of a pharmaceutical wastewater, Environ. Sci. Technol., , 40, 3971-3977.

[78] Hartig, C, Storm, T, \& Jekel, M. (1999). Detection and identification of sulphonamide drugs in municipal wastewater by liquid chromatography coupled with electrospray ionization tandem mass spectrometry. J. Chromatogr. A, , 854, 163-173.

[79] Alder, A. C, Mcardell, C. S, Golet, E. M, Ibrics, S, Molnar, E, Nipales, N. S, \& Giger, W. (2001). Occurrence and fate fluoroquinolone, macrolide and sulfonamide antibiotics during wastewater treatment and in ambient waters in Switzerland. In Pharmaceuticals and Personal Care Products in the Environment. Scientific and Regulatory Issues. Daughton, C.G. and Jones-Lepp, T. (eds). Washington D.C.. Am. Chem. Soc., , 56-69.

[80] Golet, E. M, Alder, A. C, Hartmann, A, Ternes, T. A, \& Giger, W. (2001). Trace determination of fluoroquinolone antibacterial agents in solid-phase extraction urban wastewater by and liquid chromatography with fluorescence detection. Anal. Chem. $73,3632-3638$.

[81] Lindsey, M. E, Meyer, M, \& Thurman, E. M. (2001). Analysis of trace levels of sulfonamide and tetracycline antimicrobials, in groundwater and surface water using solid-phase extraction and liquid chromatography/mass spectrometry. Anal. Chem., , 73, 4640-4646.

[82] Golet, E. M, Xifra, I, Siegrist, H, Alder, A. C, \& Giger, W. (2003). Environmental exposure assessment of fluoroquinolone antibacterial agentsfrom sewage to soil. Environ. Sci. Technol. , 37, 3243-3249. 
[83] Mcardell, C. S, Molnar, E, Suter, M. J. F, \& Giger, W. (2003). Occurrence and fate of macrolide antibiotics in wastewater treatment plants and in the Glatt Valley Watershed, Switzerland. Environ. Sci. Technol., , 37, 5479-5486.

[84] Gobel, A, Thomsen, A, Mcardell, C. S, Alder, A. C, Giger, W, Thesis, N, Löffler, D, \& Ternes, T. (2005). Extraction and determination of sulfonamide and macrolide antimicrobials and trimethoprim in sewage sludge. J. Chromatogr. A , 1085, 179-189.

[85] Drillia, P, Dokianakis, S. N, Fountoulakis, M. S, Kornaros, M, Stamatelatou, K, \& Lyberatos, K. G. (2005). On the occasional biodegradation of pharmaceuticals in the activated sludge process. The example of the antibiotic sulfamethoxazole. J. Haz. Mat. , $122,259-265$.

[86] Alexy, R, Scholl, A, \& Kummerer, K. (2004). Elimination and degradability of 18 antibiotics studied with simple tests, Chemosphere, , 57, 505-512.

[87] Matamoros, V, Caselles-osorio, A, Garcia, J, \& Bayona, J. M. (2008). Sci. Tot. Env., 394. , 171-176.

[88] Karci, A, \& Balciogli, A I. Investigation of the tetracycline, sulfonamide, and fluoroquinolone antimicrobial compounds in animal manure and agricultural soils in Turkey, Science of the Total Environment. (2009). , 407, 4652-4664.

[89] Ritmann, B E, \& Mc Carty, P L. Environmental Biotechnology: Principles and Applications, 1st ed.,U.S.A., Mc GrawHill; (2001).

[90] Lane, D J. S/23S rRNA sequencing, Nucleic acid techniques in bacterial systematics. England, Wiley;(1991). , 1991, 205-248.

[91] Takai, K, \& Horikoshi, K. Rapid detection and quantification of members of the archaeal community by quantitative PCR using fluorogenic probes. Applied Environmental Microbiology. (2000). , 66, 5066-5072.

[92] Sawayama, S, Tsukahara, K, \& Yagishita, T. Phylogenetic description of immobilized methanogenic community using real-time PCR in a fixed-bed anaerobic digester. Bioresource Technology.(2006). , 97, 69-76.

[93] Geets, J, Borremans, B, Diels, L, Springael, D, Vangronsveld, J, Van Der Lelie, D, \& Vanbroekhoven, K. DsrB gene-based DGGE for community and diversity surveys of sulfate-reducing bacteria. Journal of Microbiological Methods. (2005). , 66, 194-205.

[94] Stams, A. J. M. Oude Elferink, S. J.W.H., Westermann, P.Metabolic Interactions Between Methanogenic Consortia and Anaerobic Respiring Bacteria. In: Scheper, T. (ed.) Advances in Biochemical Engineering Biotechnology, (2003). , 31-56.

[95] Cetecioglu, Z. Evaluation of Anaerobic Biodegradability Characteristics of Antibiotics and Toxic/Inhibitory Effect on Mixed Microbial Culture. PhD Thesis. Istanbul Technical University, (2011). 
[96] Sponza, D. T, \& Demirden, P. (2007). Treatability of sulfamerazine in sequential upflow anaerobic sludge blanket reactor (UASB)/completely stirred tank reactor (CSTR) processes. Separation and Purification Technology, 56. , 108-117.

[97] Thomas, K. L, Lloyda, D, \& Boddya, L. Effects of oxygen, $\mathrm{pH}$ and nitrate concentration on denitrification by Pseudomonasspecies, FEMS Microbiology Letters, (1994).

[98] Hong, C, \& Ying, H J. LeZheng W and Bing S. Occurrence of sulfonamide antibiotics in sewage treatment plants. Chinese Science Bulletin. (2008). , 53(4), 514-520.

[99] Iwane, T, Urase, T, \& Yamamoto, K. Possible impact of treated wastewater discharge on incidence of antibiotic resistant bacteria in river water. Water Science and Technology. (2001). , 43, 91-99.

[100] Dworkin, M, Falkow, S, Rosenberg, E, Schleifer, K H, \& Stackebrandt, E. The Prokaryotes, 3nd ed., U.S.A, Springer; (2006). 
